\title{
EXOMPHALOS*
}

\section{ANALYSIS OF A 10-YEAR SERIES OF 32 CASES}

\author{
BY \\ JOHN AITKEN \\ From the Royal Hospital for Sick Children, Glasgow
}

An 'exomphalos' is a herniation of abdominal viscera into the umbilical cord; the sac consists of two layers of tissue: the inner, the peritoneum, and the outer, the amnion, which are fused together to form a thin and avascular membrane. From published reports and from examination of the defect in various patients, the condition is divisible into two types which resemble one another only superficially. The first type consists of the herniation of a loop of bowel (often the mid-gut loop) through a normally placed but abnormally large umbilical ring into the base of the cord. This has been called the 'foetal type' by Dott (1932) and 'hernia into the umbilical cord' by Margulies (1945). The second type is much larger and has been named the 'embryonic type' by Dott and 'omphalocele or amniocele' by Margulies. Here the defect in the abdominal wall far exceeds the umbilical ring in size and extends upwards towards, or actually to, the ziphisternum, the sac nearly always containing the liver as well as the bowel. The two types are not simple gradations of the same condition but originate at different developmental stages of the embryo.

\section{Embryology}

Before the tenth week of foetal life, the coelomic cavity extends into the base of the umbilical cord and contains various abdominal viscera; after the tenth week the abdominal cavity enlarges rapidly and the previously eviscerated structures are drawn into the peritoneal cavity. The formation of an exomphalos, therefore, must be due to some breakdown in this mechanism before the tenth week. Several theories have been put forward to account for such a breakdown.

(1) Permanent disparity in size between the abdominal cavity and the viscera. This view is held by Gross (1953) and Welch (1951) and could account for both types.

(2) Margulies believes that the second type

* A paper read at a meeting of the British Association of Paediatric Surgeons in London, September 1962. (amniocele) is due to failure of development and closure of the anterior abdominal wall above the umbilicus at the third week of foetal life. This occurs either because of failure of fusion between the amniotic covering and the transverse septum or because of failure of proliferation of the latter, and results in an amnion-covered gap in the supraumbilical abdominal wall. The first type (hernia into cord) he considers to be due to failure of the intestine to retract, or to failure of proliferation of the adventitial tissue around the umbilical vessels, such errors occurring at the eighth to tenth week of foetal life.

(3) Dott suggests that pressure of the liver, which has become abnormally adherent to the amnion before the formation of the coelom at or about the third week, may cause a sac to remain into which viscera herniate.

\section{Clinical Features}

The greater diameter of any exomphalos sac may vary from as little as $2 \mathrm{~cm}$. to that of a grapefruit, but this measurement bears little relation to the size of the defect in the abdominal wall. Those with a small opening actually at the site of the umbilicus are of Type 1 'umbilical cord hernia'. In these the cord is attached to the apex of the sac which usually contains bowel only. In Type 2 'amniocele' the defect extends a varying distance supra-umbilically and the cord is attached caudal to the sac apex.

If the infant is born with the sac intact, as a rule it will remain so for about 24 hours, gradually drying and becoming friable and eventually rupturing. Rupture may also occur in utero or during birth; in the former case all the coils of bowel will be oedematous, friable and matted together, but in the latter instance, at least at first, the bowel will be smooth, shiny and non-adherent. Naturally, the prognosis is much better in the second type.

As long as the sac is intact, babies show little evidence of distress or discomfort. Once rupture 
has occurred, however, the onset of shock, vomiting, dehydration and infection is not long delayed.

Other congenital anomalies are frequent accompaniments. One group of these affects the sac contents, e.g. malrotation of the bowel and volvulus; and the other, some other part of the body such as heart, great vessels, or spine.

\section{Present Series}

There were nine cases of amnioceles and 23 of herniae into cord.

There were 18 males and 14 females, and of these, 24 were full term, i.e. over $5 \mathrm{lb} .(2 \cdot 26 \mathrm{~kg}$.), and eight premature. The overall mortality was $56 \%$. Ten $(42 \%)$ full term and seven $(88 \%)$ premature infants died.

Rupture of Sac. Eight infants in the series had ruptured sacs, five of which were intrauterine. Four of these babies were full term, one with an intrauterine rupture died; the four others were premature, all had intrauterine ruptures and all died. Of the three recoveries, one had an amniocele which was repaired in two stages, the other two had herniae into the cord.

Other Abnormalities (Table 1). In this series of 32 cases, 10 infants $(31 \%)$ had congenital abnormalities other than those affecting the gastrointestinal tract; eight of them died from cardiovascular anomalies.

Operative Treatment (Table 2). Thirty-one patients were operated on, all within 24 hours of birth. One infant with a very small sac and numerous other congenital defects was treated conservatively with locally applied mercurochrome. The 'Standard' procedure consisted of immediate complete repair of the abdominal wall with excision of the sac. The 'two stage' operation comprised the closure of undermined skin over the intact sac at the first stage. Of the four patients treated thus, only one survived for the second operation of abdominal wall repair; he is now alive and well.

Size of Defect (Table 3). This is only a measurement of the width of the gap in the abdominal wall, the diameter of the sac itself was usually considerably greater. A gap diameter of $4 \mathrm{~cm}$. was the greatest seen in the 'hernia into the cord' type. All those over $4 \mathrm{~cm}$. (nine cases) were of the 'amniocele' type with the typical deficiency in the supraumbilical wall.
TABLE 1

OTHER CONGENITAL ABNORMALITIES

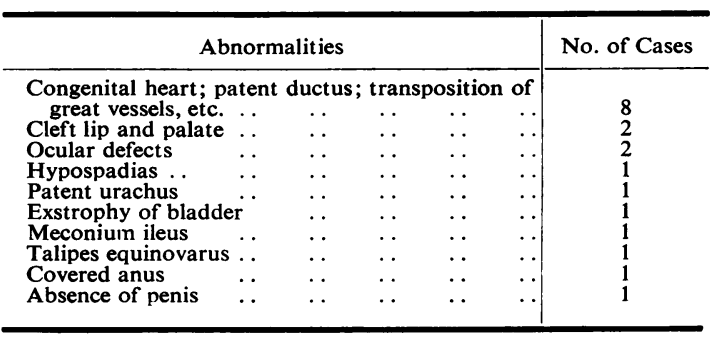

These anomalies affected 10 patients of whom eight died.

TABLE 2

OPERATIONS

All performed within 24 hours

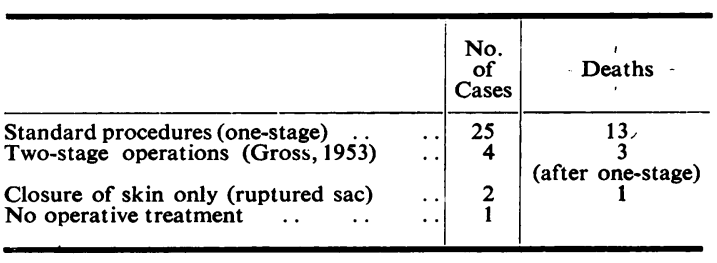

Contents of Sac (Table 4). As was to be expected from the way in which the bowel is normally drawn into the enlarging foetal abdomen, sacs containing the mid-gut loop or the mid-gut loop with liver and other viscera were by far the commonest.

Anomalies of Contents (Table 5). The three cases with small gut only in the sac had no abnormality

TABLE 3

SITE OF DEFECT

\begin{tabular}{|c|c|c|}
\hline Defect & No. of Cases & Deaths \\
\hline $\begin{array}{l}\text { Amniocele }(>4 \mathrm{~cm} . \text { diam. }) \\
\text { Hernia into cord }(<4 \mathrm{~cm} \text {. diam.) }\end{array}$ & $\begin{array}{r}9 \\
23\end{array}$ & $\begin{array}{l}8 \\
9\end{array}$ \\
\hline
\end{tabular}

TABLE 4

CONTENTS OF SAC

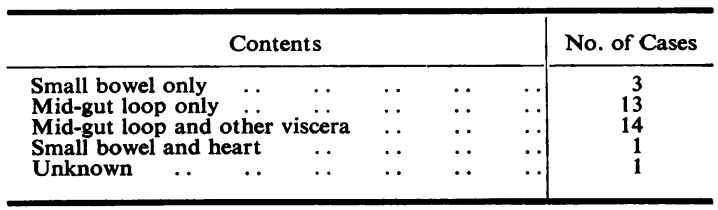


TABLE 5

ANOMALIES OF CONTENTS

\begin{tabular}{|c|c|}
\hline Contents & No. of Cases \\
\hline $\begin{array}{l}\begin{array}{l}\text { Meckel's diverticulum (adherent to sac in 7, hernia } \\
\text { into cord) }\end{array} \\
\left.\begin{array}{l}\text { Patent vitello-intest inal duct (hernia into cord) } \\
\text { Malrotation } \\
\begin{array}{l}\text { Malrotation and volvulus } \\
\text { Duplication of ileum } \\
\text { Heart (hernia of ventricle) }\end{array}\end{array}\right\} \text { Amnioceles }\end{array}$ & $\begin{array}{l}8 \\
2 \\
3 \\
2 \\
1 \\
1\end{array}$ \\
\hline
\end{tabular}

of the contents. Eight Meckel's diverticula were found, seven of them in the 'hernia into the cord' type; these were adherent to the apex of the sac which contained the mid-gut loop only. The remaining one, in an amniocele, was non-adherent and this sac contained mid-gut, liver and stomach and also a small ileal duplication. A patent vitello-intestinal duct was found in two other instances of hernia into the cord. The five cases of malrotation, and malrotation and volvulus were found exclusively in the amniocele type.

Analysis of Deaths (Table 6). Autopsies were carried out in four of the eight patients with amnioceles who died. Three of these had gross vascular defects incompatible with life (Cases 3,5 and 8). One (Case 6), after thriving at home for some weeks, died of intestinal obstruction from a malrotation, which was missed at the original operation. Cases
1 and 2 probably died of respiratory embarrassment due to increased abdominal pressure as their defects were very large. One was premature and the other only $5 \mathrm{lb}$. $(2 \cdot 26 \mathrm{~kg}$.). The remaining two (Cases 4 and 7) died of cold injury with gross sclerema; cardiovascular defects were almost certainly present in them also.

Five (Cases 10, 11, 14, 15 and 16) of the nine patients with 'hernia into the cord' who died had gross cardiac defects incompatible with life (Table 7). Two (Cases 13 and 17) had malrotation with volvulus and gangrene of the involved bowel. One died of 'peritonitis' (Case 12) and one (Case 9) of pneumonia two months after operation.

\section{Discussion and Summary}

In this series the hernia into the cord type of exomphalos was by far the commoner with a ratio of $24: 8$. This is probably the usual finding, although many textbooks and many of the published reports do not differentiate between the two types. Both Gross (1953) and Swenson (1958), for example, discuss the two conditions together under the heading of 'omphalocele' and only distinguish between this and the common umbilical hernia of postnatal type. If only from the point of view of mortality, it seems better to make a distinction; in a series in which there were few or no cases of amniocele, a wrong impression could easily be given.

TABLE 6

ANALYSIS OF DEATHS-'AMNIOCELES'

\begin{tabular}{|c|c|c|c|c|c|}
\hline $\begin{array}{l}\text { Case } \\
\text { No. }\end{array}$ & $\begin{array}{l}\text { Size of } \\
\text { Defect } \\
\text { (cm.) }\end{array}$ & $\begin{array}{l}\text { Contents of Sac } \\
\text { and } \\
\text { Anomalies }\end{array}$ & Treatment & $\begin{array}{c}\text { Time of Death } \\
\text { After Operation } \\
\text { (hrs) }\end{array}$ & $\begin{array}{l}\text { Cause of Death } \\
\text { and/or } \\
\text { Findings at Autopsy }\end{array}$ \\
\hline $1 *$ & 'Gross' & Mid-gut and liver & 1st stage of two-stage & 24 & $\begin{array}{l}?++ \text { intra-abdominal pressure } \\
\text { (no autopsy) }\end{array}$ \\
\hline $2 \dagger$ & $7 \cdot 5$ & Small gut, liver and stomach & 1st stage of two-stage & 12 & $\begin{array}{l}?++ \text { intra-abdominal pressure } \\
\text { (no autopsy) }\end{array}$ \\
\hline 3 & 'I.arge' & All gut and liver & One-stage & 48 & $\begin{array}{l}\text { Cardiac failure } \\
\text { Very large ductus }\end{array}$ \\
\hline 4 & 9 & All gut, stomach and liver & One-stage & 9 & $\begin{array}{l}\text { Sclerema and cold injury (no } \\
\text { autopsy) }\end{array}$ \\
\hline $5 \ddagger$ & 5 & Mid-gut and Meckel & One-stage; res. of Meckel & 16 & Intraventricular septal defect; \\
\hline 6 & 6 & $\begin{array}{l}\text { Small gut and liver mal- } \\
\text { rotation }\end{array}$ & One-stage & 6 wks & $\begin{array}{l}\text { atelectasis both lungs } \\
\text { Intestinal obstruction due to } \\
\text { missed malrotation }\end{array}$ \\
\hline 7 & 7 & $\begin{array}{l}\text { A!l gut, liver and spleen; } \\
\text { Meckel }\end{array}$ & Ist stage of two-stage & 6 & $\begin{array}{l}\text { Sclerema and cold injury (no } \\
\text { autopsy) }\end{array}$ \\
\hline 8 & $5 \cdot 5$ & $\underset{\text { ventricle) }}{\text { Small gut and heart (left }}$ & One-stage & 3 & $\begin{array}{l}\text { Hernia of ventricle } \\
\text { Intraventricular septal defect } \\
\text { Transposition of great vessels }\end{array}$ \\
\hline
\end{tabular}

In none of these cases was the sac ruptured.

* Case 1 was premature, weighing $4 \mathrm{lb}$. (1.8 kg.)

$\dagger$ Case 2 was mature, but weighed only $5 \mathrm{lb}$. $(2 \cdot 26 \mathrm{~kg}$.).

$\ddagger$ Case 5 was premature, weighing $4 \frac{1}{2} \mathrm{lb}$. $(2 \cdot 03 \mathrm{~kg}$.). 
TABLE 7

ANALYSIS OF DEATHS-'HERNIA INTO CORD'

\begin{tabular}{|c|c|c|c|c|c|c|}
\hline $\begin{array}{l}\text { Case } \\
\text { No. }\end{array}$ & $\begin{array}{l}\text { Size of } \\
\text { Defect } \\
\text { (cm.) }\end{array}$ & $\begin{array}{c}\text { Sac } \\
\text { (Ruptured or } \\
\text { Unruptured) }\end{array}$ & $\begin{array}{l}\text { Contents of Sac } \\
\text { and } \\
\text { Anomalies }\end{array}$ & Treatment & $\begin{array}{l}\text { Time of Death } \\
\text { After Operation } \\
\text { (hours) }\end{array}$ & $\begin{array}{l}\text { Cause of Death; } \\
\text { Findings at } \\
\text { Autopsy }\end{array}$ \\
\hline 9 & 4 & $\mathbf{U}$ & Mid-gut loop & One-stage & $2 \mathrm{mths}$ & Bronchopneumonia \\
\hline $10^{*}$ & $?$ & $\mathbf{U}$ & Mid-gut loop & One-stage & 24 & Intraventricular septal defect \\
\hline 11 & 3 & $\mathbf{U}$ & $\begin{array}{l}\text { Mid-gut loop; adherent } \\
\text { Meckel }\end{array}$ & $\begin{array}{l}\text { One-stage; res. of } \\
\text { Meckel }\end{array}$ & 48 & $\begin{array}{l}\text { Gross congenital heart; } \\
\text { intraventricular septal } \\
\text { defect, etc. }\end{array}$ \\
\hline $12^{*}$ & $2 \cdot 5$ & $\mathbf{R}$ & All snall gut; stomach & One-stage & 92 & Peritonitis (no autopsy) \\
\hline 13 & 3 & $\mathbf{R}$ & $\begin{array}{l}\text { All gut and liver; mal- } \\
\text { rotation and volvulus }\end{array}$ & $\begin{array}{l}\text { One-stage; correction } \\
\text { of malrotation }\end{array}$ & 16 & $\begin{array}{l}\text { Mesenteric thrombosis: } \\
\text { peritonitis }\end{array}$ \\
\hline $14^{*}$ & 4 & $\mathbf{R}$ & $\begin{array}{l}\text { Mid-gut loop; adherent } \\
\text { Meckel; ileal dupli- } \\
\text { cation }\end{array}$ & $\begin{array}{l}\text { One-stage; res. of } \\
\text { Meckel and duplica- } \\
\text { tion }\end{array}$ & 12 & $\begin{array}{l}\text { Gross congenital heart; } \\
\text { meconium ileus }\end{array}$ \\
\hline 15 & $2 \cdot 5$ & $\mathbf{U}$ & Mid-gut loop & One-stage & 72 & Very large ductus \\
\hline $16^{*}$ & 2 & $\mathbf{R}$ & $\begin{array}{l}\text { Mid-gut loop with vit- } \\
\text { ello intestinal fistula }\end{array}$ & $\begin{array}{l}\text { One-stage with res. of } \\
\text { fistula }\end{array}$ & 24 & $\begin{array}{l}\text { Intraventricular septal defect } \\
\text { and transposition of great } \\
\text { vessels }\end{array}$ \\
\hline $17 *$ & 3 & $\mathbf{R}$ & $\begin{array}{l}\text { All gut and stomach; } \\
\text { malrotation and vol- } \\
\text { vulus }\end{array}$ & $\begin{array}{l}\text { One-stage; correction } \\
\text { of volvulus }\end{array}$ & 3 & $\begin{array}{l}\text { Mesenteric thrombosis and } \\
\text { gangrene }\end{array}$ \\
\hline
\end{tabular}

* Cases 10, 12, 14, 16 and 17 weighing $3 \mathrm{lb} .(1 \cdot 36 \mathrm{~kg}),. 3 \frac{1}{2} \mathrm{lb} .(1 \cdot 6 \mathrm{~kg}),. 3 \mathrm{lb} .(1 \cdot 36 \mathrm{~kg}),. 4 \frac{1}{2} \mathrm{lb} .(2 \cdot 03 \mathrm{~kg}$.$) and 4 \mathrm{lb} .(1 \cdot 8 \mathrm{~kg}$. respectively, were all premature.

Of 32 sacs, eight were ruptured; unexpectedly, only one of these was an amniocele; this patient and two others survived, probably because their ruptures were extrauterine. No patient with an intrauterine rupture recovered.

Ten patients ( $31 \%$ ) had congenital abnormalities other than the exomphalos and its contents; Gross quoted $59 \%$ in his series and remarked that in the majority anomalies were of a minor character. This has not been our experience; eight of our 10 patients with these abnormalities died of cardiovascular defects incompatible with life.

As might be expected from the embryology of the umbilical region, anomalies of the exomphalos contents were common and comprised Meckel's diverticulum (eight cases), patent vitello-intestinal duct (two cases) and malrotation with or without volvulus (five cases). Regarding the Meckel's diverticula, in eight (all hernia into cord) of the nine cases at operation, the diverticulum was found to be densely adherent to the sac at the origin of the umbilical cord and had to be resected before the sac could be removed. Benson, Penberthy and Hill (1949) found two similar diverticula in a series of only seven patients. It seems that this finding makes the treatment suggested by Nixon and O'Donnell (1961) a dangerous one in such cases; twisting the unopened sac to cause reduction of the contents and fixing it thus would surely lead to gangrene of a trapped adherent diverticulum and hence to disaster.

Malrotation, with or without volvulus, was found in five $(55 \%)$ of our amniocele cases (Gross quotes $28 \%$ in his series). That this associated abnormality should be common in the amniocele is not surprising, since both defects occur at the same embryological time.

The mortality of $56 \%$ in this series is a high one, but is accounted for largely by the type of case encountered. Reference to Tables 6 and 7 makes this clear.

\section{REFERENCES}

Benson, C. D., Penberthy, G. C. and Hill, E. J. (1949). Arch. Surg., $58,833$.

Dott, N. M. (1932). Trans. Edinb. obstet. Soc., 52, 105.

Gross, R. E. (1953). Surgery of Infancy and Childhood. Saunders, Philadelphia.

Margulies, L. (1945). Amer. J. Obstet. Gynec., 49, 695.

Nixon, H. H. and O'Donnell, B. (1961). The Essentials of Paediatric Surgery. Heinemann, London.

Swenson, O. (1958). Pediatric Surgery. Appleton, New York. Welch, K. J. (1951). Surgery, 29, 100. 